\title{
The Effect of Renting in Cropland on Livelihood Choices and Agricultural Commercialization: A Case Study from Rural Vietnam
}

\author{
Oliver Schulte $^{1}$ (D) Trung Thanh Nguyen ${ }^{1} \cdot$ Ulrike Grote $^{1}$
}

Accepted: 8 November 2021 / Published online: 15 February 2022

(c) The Author(s) 2022

\begin{abstract}
This paper investigates the role of land rental markets in livelihood choices using data from 792 farming households in rural Vietnam. First, we cluster households according to livelihood strategies and estimate the determinants of the respective decision. In a second step, we analyze the contribution of rented land in linking smallholders to output markets. Our results suggest that rented land can provide smallholders with an opportunity to increase their agricultural activities and avoid resorting to less remunerative activities such as agricultural wage labor. Moreover, rented crop area increases the probability of market participation as well as the quantity of sales. Our results point to the need for a further liberalization of land rental markets specifically targeted at households that have been excluded from more remunerative livelihood strategies previously. Supporting these households to have access to the assets required to cultivate the additional area is thus recommended.
\end{abstract}

Keywords Livelihoods · Commercialization · Control function · Double-Hurdle · Land markets

\section{Résumé}

Cet article étudie le rôle que jouent les marchés de location de terres agricoles dans les choix de moyens de subsistance, à l'aide de données issues de 792 ménages agricoles dans les zones rurales du Vietnam. Tout d'abord, nous regroupons les ménages en fonction de leur stratégie de subsistance et nous estimons les déterminants qui sous-tendent la décision de chacun. Nous analysons ensuite le lien entre la mise en location des terres et le lien créé entre les petits exploitants et les marchés de production. Nos résultats suggèrent que la mise en location des terres peut offrir aux petits exploitants l'opportunité d'augmenter leurs activités agricoles et d'éviter d'avoir à recourir à des activités moins rémunératrices telles que le travail agricole salarié. De

Oliver Schulte

schulte@iuw.uni-hannover.de

1 Institute for Environmental Economics and World Trade, Leibniz University Hannover,

Königsworther Platz 1, 30167 Hannover, Lower Saxony, Germany 
plus, la mise en location de terres agricoles augmente la probabilité de participer au marché ainsi que la quantité de ventes. Nos résultats soulignent la nécessité d'une plus grande libéralisation des marchés de location de terres en ciblant plus particulièrement les ménages qui ont auparavant été exclus des stratégies de subsistance qui rapportent le plus. Il est donc recommandé d'accompagner ces ménages pour qu'ils aient accès aux biens nécessaires pour cultiver la surface supplémentaire.

\section{Introduction}

The fixed amount of fertile land constitutes a key constraint in expanding agricultural production (Bruinsma 2011). Simultaneously, land continues to play a major role in supporting rural livelihoods. Vietnam's per capita arable land endowment of 0.0747 hectare is the lowest in the Mekong region, and very small by global standards (World Bank 2020). A system of temporal land-use rights ensures that the public ownership of land remains largely untouched (Gillespie and Le 2018; Hirsch et al. 2015), and as a result of egalitarian distribution, very small farm sizes and high levels of fragmentation persist (World Bank 2016; Markussen 2015; Tran and van $\mathrm{Vu}$ 2019). Given this situation, land rental and sales markets could represent viable policy tools that can contribute to the improvements of rural livelihoods (Deininger 2003; Muraoka et al. 2018; Nguyen et al. 2021). The aim of our study is twofold. First, we evaluate whether renting in additional cropland is associated with distinct livelihood strategies in the present. Secondly, we assess whether rented land area affects the decisions of rural households to participate in output markets, and the quantities supplied to those markets.

In our conceptual framework, we show that rented farmland can be considered part of natural capital (Nguyen et al. 2015a, b; Nielsen et al. 2013). The attainable scope for crop production widens once a household is able to access additional cropland, leading to income gains from farming (Huy et al. 2016; Muraoka et al. 2018; Huy and Nguyen 2019; Nguyen et al. 2021; Zhang et al. 2018). Therefore, renting in land can be expected to facilitate the expansion of livelihood choices available to households. This is intricately connected to the role of land in commercialization. Owning a larger cropland area is typically found to be associated with a higher likelihood of participating in output markets, and increased sales in these markets conditional on participation (Woldeyohanes et al. 2017; Alene et al. 2008; Kissoly 2016). However, to the best of our knowledge, the role of rented land has not been sufficiently considered in the literature.

Vietnam presents an optimal case for the study of rural households' commercialization, as a structural transformation of the rural sector has contributed significantly to growth and exports (Cazzuffi et al. 2020). At the same time, rental markets have achieved considerable coverage in recent years (Markussen 2015). Our paper contributes to the debate on the role of rental markets by pointing out how they can facilitate linking smallholders to markets and increase sales. In rapidly developing economies such as Vietnam, land rental markets can thus help promote rural transformation. 
The remaining of our paper is structured as follows: In Section "Literature Review and Background", we present the state of literature with respect to land rental markets and agricultural commercialization, and provide some background information on Vietnam. Building on these sections, we present our adaptation of the sustainable livelihoods framework in Section "Conceptual Framework". Sections "Identification of Livelihood Strategies: Factor and Cluster Analysis", "Identification of Determinants of Livelihood Choices", and "Double-Hurdle Model of Output Market Participation and Sales Quantity" are dedicated to our empirical strategy. We employ factor and cluster analysis to identify livelihood strategies of our sample households, identify determinants of these strategies in a multinomial logit regression, and analyze the determinants of market participation and sales quantity with the help of a double-hurdle model. Section "Data and Descriptive Statistics by Livelihood Clusters" presents the data we employ, and descriptive statistics by livelihood clusters. Sections "Determinants of Household Livelihood Strategies and Determinants of Commercialization" contain the results of our main regressions. Section Conclusion concludes the paper.

\section{Literature Review and Background}

In the presence of imperfect labor markets, land rental markets can facilitate the adaptation of households to efficient levels of crop cultivation (Deininger 2003). This is of special relevance to developing countries, where rural households are rather land- than labor-constrained (Deininger 2003; World Bank 2016). This constraint is even more likely to affect rural households in Vietnam, where farms are on average very small and fragmented (Huy et al. 2016; Marsh et al. 2006). The hypothesis that land-constrained households are more likely to rent in is commonly supported by empirical evidence (Deininger and Jin 2005; Jin and Deininger 2009; Jin and Jayne 2013; Muraoka et al. 2018; Nguyen et al. 2021). Complementary to this, rental market participation as lessee is typically found to increase in the number of working age household members (Deininger and Jin 2008; Jin and Deininger 2009; Jin and Jayne 2013; Muraoka et al. 2018).

Previous research on income effects provides some guidance as to which livelihood strategies households pursue when participating in land rental markets. Renting in is usually associated with increased farm incomes (Jin and Jayne 2013; Muraoka et al. 2018). Renting out has been found to contribute to increased off-farm activities (Nguyen et al. 2021), and a higher chance for households to escape poverty (Ghebru and Holden 2019). However, research on the effect of rented land on households' livelihood strategies remains scarce. Zhang et al. (2019) control for renting in in their study of Chinese households and present results suggestive of a negative effect on upward mobility in livelihood transitions. We build on these considerations by explicitly considering different clusters of livelihood strategies, which provide us with a more nuanced picture of rural life than the dichotomy of farm and off-farm 
income. We add to this methodological contribution by accounting for the possible endogeneity of rental decisions with the help of a control function approach.

A focus of our work is on agricultural commercialization, routinely presented as the share of output sold on markets (see for instance Cazzuffi et al. (2020), Ogutu and Qaim (2019)). The availability of inputs such as land, labor, or farming assets has repeatedly been found to increase a household's commercialization (Braun and Immink 1994; Omiti et al. 2009; Muriithi and Matz 2014; Dube 2016; Alene et al. 2008; Kissoly 2016). However, none of these studies have accounted for the possibility that households adapt the land area they cultivate. Chapoto et al. (2013) analyze the transition of a set of Ghanaian smallholder farmers to medium- and large-scale farmers, but do so only for a very small sample. Gebru et al (2019) study the access of smallholder tenants to land in Ethiopia from 1998 to 2015, assuming that access to land will lead to intensified farming activities. However, their finding that inefficient land rental markets constrain the commercialization of smallholder farmers is problematic, as they equate the cultivation of a larger area with commercialization.

The shortage of research on this topic is somewhat puzzling. Linking smallholders to markets and increasing the marketed quantity have been perceived as desirable livelihood outcomes. Increased levels of commercialization have been associated with higher gross crop output and net per capita incomes (Tipraqsa and Schreinemachers 2009), or higher incomes and added nutrients (Ogutu et al. 2017). Moreover, both income and multidimensional poverty are reduced by commercialization (Ogutu and Qaim 2019). In Vietnam, commercialization has been found to positively affect asset accumulation, mainly due to the sales of crops other than rice (Cazzuffi et al. 2020). Our paper adds to the scarce literature in several ways. In the conceptual framework, we discuss how rented area could assist households in overcoming fixed and proportional transaction costs in output markets. By estimating a double-hurdle model in the analysis, we account for these considerations, and provide support to the notion that farming households face several bottlenecks at different stages of their marketing decisions.

Within the last decades, agriculture in Vietnam has moved from a situation of mainly collective production to one that is characterized by the decision-making of households under considerable public control and possibly interference (Gillespie and Le 2018; Hirsch et al. 2015). Land has been received and disposed of by individual households by a mix of market-based transactions and administrative reallocations (Ravallion and van de Walle 2008, p. 102). Markets in land-use rights were quite active in the decade following the 1993 land law (Ravallion and van de Walle 2008). During the Đổi mó $i$ reforms, the rural economy also witnessed an increasing diversification toward non-farm activities (Pham et al. 2010). Typically, the poorer households derive a large fraction of their income from agricultural activities, benefiting less from non-farm activities (Pham et al. 2010; Tran 2016). Larger landholdings have been found to reduce the participation in non-farm activities (Pham et al. 2010). Moreover, the area of annual cropland owned by a household seems to enable it to either intensify its agricultural activities, or to move into formal wage work, non-wage-earning work, and obtain non-labor income (Hoang et al. 2019). Households can resort to agricultural wage labor, but due to its seasonality and comparatively low wages, it has often been described as a livelihood activity of last 
resort (Brünjes and Revilla Diez 2016; Akram-Lodhi 2005; Prota and Beresford 2012; Quang 2018). Households can also choose migration of one or several members to obtain employment elsewhere, especially in provinces with poor employment and job opportunities (Nguyen et al. 2015a, b). Migrants are usually young and well-trained, and move to the urban centers (GSO 2011, 2015). Another important income source for many households is the extraction of natural resources by activities such as hunting, fishing, logging, collecting non-timber forest products, which provides income to both poor and non-poor households (Nguyen and Tran 2018; McElwee 2008; Nguyen et al. 2015a, b).

\section{Conceptual Framework and Empirical Strategy}

\section{Conceptual Framework}

Our conceptual framework is presented in Fig. 1. We rely on the livelihoods approach to describe the sample households' patterns of activities (Momtaz and Shameem 2016; Ashley and Carney 1999). A livelihood consists of the capabilities, assets, and activities that are required for a means of living (Serrat 2008; Ashley and Carney 1999). The access to livelihood assets differs between households, and usually entails trade-offs and choices for poor households (Serrat 2008; Nielsen et al. 2013). By allocating its assets to different activity choices, a household achieves a set of livelihood outcomes (Nguyen et al. 2015a, b). First, we turn to the link between rented land and agricultural production. Limited access to land has been shown to pose significant constraints on rural households (Hoang et al. 2019). Studies from other world regions have highlighted the role that rented land could play in enabling young and land-constrained farmers to access land (Ricker-Gilbert and Chamberlin 2018; Gebru et al. 2019). Our framework captures how overcoming limited access to

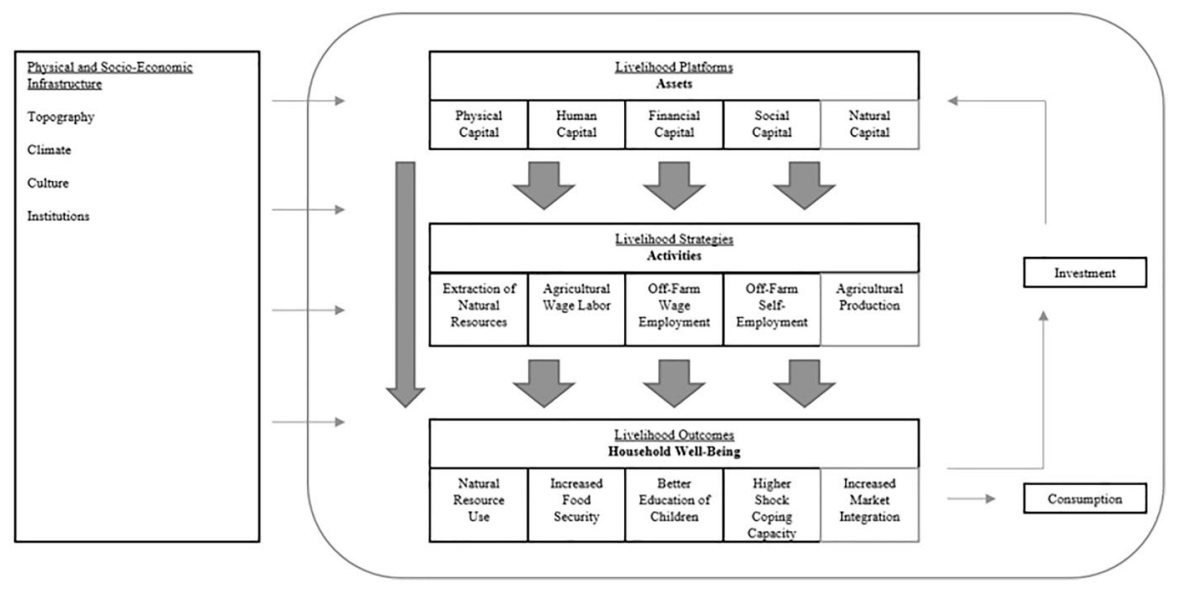

Fig. 1 Household livelihood strategy framework ( Source: Modified from Nielsen et al. 2013, Nguyen et al. 2015a, b) 
cropland might prevent households with little household capital from being deprived of the opportunity to rely on agriculture, forcing them into the least remunerative activities instead. Recent literature on livelihood strategies has highlighted the importance of dynamic modeling that considers the transition of household between periods (Zhang et al. 2019; Waledign 2017). However, the transition between livelihood strategies is not the point of interest of this study. One of the most important characteristics of land rental markets is that they provide households with a flexible short-term instrument. For that reason, we prefer the cross-sectional perspective over a longitudinal perspective. To meet any concerns regarding the endogeneity of short-term rental decisions, we employ a control function approach, as discussed in Section Identification of Determinants of Livelihood Choices.

In the second part of our analysis, we focus on livelihood outcomes. We consider the increased market integration of farming households. We can express a household's discrete output market participation decision $q_{s j}^{p}$ as a function of the price $p^{m}$ of good $j$, the fixed transaction $\operatorname{cost} \tau^{f}$, and proportional costs $\tau^{v}$ incurred by the household when selling in markets, and demographic and production characteristics $z_{\boldsymbol{u}}$ and $z_{\boldsymbol{q}}$ (Goetz 1992; Key et al. 2000; Woldeyohanes et al. 2017; Alene et al. 2008):

$$
q_{s j}^{p}=f\left(p_{j}^{m}, \tau^{f}, \tau^{v}, z_{u}, z_{q}\right)
$$

The decision on the quantity supplied to markets, $q_{s j}$, conditional on market participation, is expressed as a function of market price, proportional transaction costs, and production characteristics (Woldeyohanes et al. 2017):

$$
q_{s j}=f\left(p_{j}^{m}-\tau^{v}, z_{q}\right)
$$

Renting in can be hypothesized to affect both decisions through two mechanisms. First, physical assets can enhance production (Barrett 2008), facilitate the production of marketable surplus, and provide economies of scale (Kissoly 2016). In addition, renting in has been identified as a tool to adapt the ratio of land to family labor to more efficient levels (Jin and Jayne 2013). These effects would be captured in the vector of production characteristics. Secondly, access to additional assets such as cropland might mitigate the effects of fixed and proportional transaction cost households face in output markets (Woldeyohanes et al. 2017; Winter-Nelson and Temu 2005). Such changes in production characteristics and transaction costs brought about by renting in would positively affect both the market participation decision and the quantity supplied to markets.

$$
\begin{gathered}
\frac{\partial q_{\mathrm{sj}}^{\mathrm{p}}}{\partial \operatorname{Rent}}>0 \\
\frac{\partial q_{\mathrm{sj}}}{\partial \operatorname{Rent}}>0
\end{gathered}
$$




\section{Identification of Livelihood Strategies: Factor and Cluster Analysis}

In order to identify specific livelihood strategies rather than just different mixes of similar activities, we employ cluster analysis, which can be based on income- or asset-based measures (Nguyen et al. 2015a, b; Nielsen et al. 2013) Using income shares in cluster analysis has been criticized due to the short-term and stochastic nature of income (Jansen et al. 2006; Nielsen et al. 2013). However, it is possible to complement the income data with information on assets and activities of the household (Nguyen et al. 2015a, b). Before we turn to the cluster analysis, we execute a factor analysis to identify major factors. We consider 11 variables that describe the sources of a household's income, and complement them with five variables that describe expenditures on productive activities (Hoang et al. 2019). We test and confirm that the data are suited for factor analysis by means of a correlation matrix, the Bartlett-test of sphericity, an anti-image-covariance-matrix, and the Kaiser-Meyer-Olkin criterion (Backhaus et al. 2011). We use principal component analysis requiring factor loadings larger than 0.3 , and obtain six factors by means of orthogonal varimax rotation (Backhaus et al. 2011). Departing from the predicted factor scores, we use Ward's method which has been found to produce good partitions and assign elements correctly to their specific groups (Bergs 1981). We use the squared Euclidean distance and draw on the metric factors obtained in the factor analysis to improve performance. The Calinski/Harabasz stopping rule is employed to determine the optimal number of clusters by identifying the peak of the pseudo-F, which is at 5 groups for our sample. A descriptive analysis by cluster can be found in Table 1 in Section "Data and Descriptive Statistics by Livelihood Clusters", where we also discuss the characteristics of each cluster.

\section{Identification of Determinants of Livelihood Choices}

To estimate the effect of different livelihood platforms on the livelihood choices of households, we employ a multinomial logit model (MNL). The chance $C_{i j}$ of household $i$ to belong to cluster $j$ serves as dependent variable. In line with our theoretical framework, we include measures on natural $(\mathrm{N})$, physical $(\mathrm{P})$, human $(\mathrm{H})$, financial (F), and social (S) capital (Nguyen et al. 2015a, b; Nielsen et al. 2013). Adding the stochastic error term $\epsilon_{i j}$, the regression model takes the following form:

$$
C_{i j}=\beta_{0}+\beta_{1} \operatorname{RentIn}_{i j}+\beta_{2} \operatorname{RentOut}_{i j}+\beta_{3} N_{i j}+\beta_{4} P_{i j}+\beta_{5} H_{i j}+\beta_{6} F_{i j}+\beta_{7} S_{i j}+\epsilon_{i j}
$$

Our main variables of interest are whether a household rents in land (RentIn), and whether it rents out any land (RentOut). A positive significant coefficient for renting in indicates that access to land enables households to move into the respective livelihood cluster $j$. To rule out any concerns about multicollinearity, we checked the mean variance inflation factor, which is well below conventional thresholds.

However, including rental decisions entails some caveats. We suspect that land area rented in, as short-term adaptable asset, might be jointly determined with households' livelihood choices (Hoang et al. 2019; Jansen et al. 2006). Incorporating 


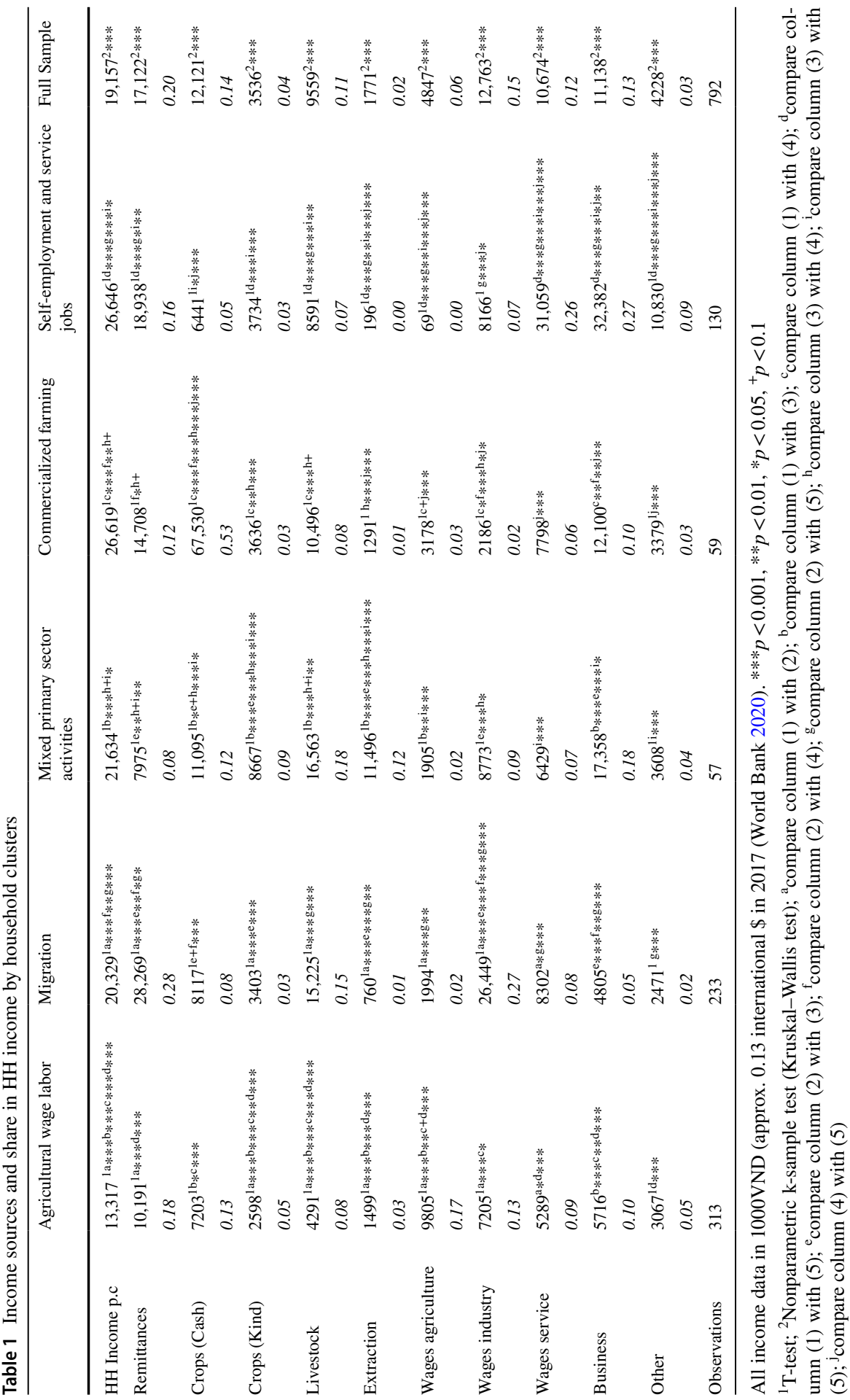

象 
a control function approach can account for this possible source of endogeneity (Wooldridge 2005). Including the predicted residuals from a reduced form equation with a set of exogenous instruments corrects for endogeneity, if a significant coefficient allows to reject exogeneity. Otherwise, we exclude the residual term to produce more efficient and unbiased estimates (Wooldridge 2010, 2015; Petrin and Train 2010). The control function approach has become popular in empirical applications due to its applicability to non-linear models (Ogutu and Qaim 2019), and control functions have been combined with logit models routinely (Petrin and Train 2010). We use the percentage of households in the subdistrict that participate in rental markets as exogenous instrument in a Tobit estimation for the land area rented in. The instrument captures that participation of other households can reduce the transaction cost that often depress participation in those markets (Deininger and Jin 2008; Huy et al. 2016; Muraoka et al. 2018).

\section{Double-Hurdle Model of Output Market Participation and Sales Quantity}

To estimate the effect of crop area rented in on market participation and quantity of sales, we employ a double-hurdle model by Cragg (1971). Treating no sales as rational corner solution precludes the use of the Heckman (1979) sample selection model. Unlike in the Tobit estimator by Tobin (1958), covariates can have effects of different signs on the participation and sales quantity in the double-hurdle model, while their relative effects can also differ (Woldeyohanes et al. 2017; Wooldridge 2010; Cameron and Trivedi 2010). Employing this estimator thus allows us to study the effect of rented land and other variables on decisions that are assumed to be independent (Bezu et al. 2014). We choose a log specification because of some high sales values. For the first hurdle, we fit a probit estimator that models the household's participation decision. In the second hurdle, the quantity sold by those households selling in markets serves as dependent variable. This stage is estimated with a truncated normal regression. We use the craggit Stata command, which is provided in Burke (2009). The appropriateness of our specification against the alternative of the one-step Tobit estimator was tested with an LR-test (Woldeyohanes et al. 2017) and by comparing the log-likelihood of both estimations (Cameron and Trivedi 2010, p. 540). We compared our set of control variables with the most common ones employed in studies on agricultural sales of households (Dube 2016; Muriithi and Matz 2014; Omiti et al. 2009; Kissoly 2016).

\section{Data and Descriptive Statistics by Livelihood Clusters}

Our data were gathered in 2017 in a survey of 1898 households in the rural Vietnamese provinces presented in Fig. 2. Data collection was organized and executed within the research project "Thailand Vietnam Socio-economic Panel (TVSEP)" 0.1 the sampling of the provinces ensures that these are representative of rural provinces in Central Vietnam, which are characterized by an enduring importance of agriculture, low incomes, and poor infrastructural conditions (Hardeweg et al. 2013). 


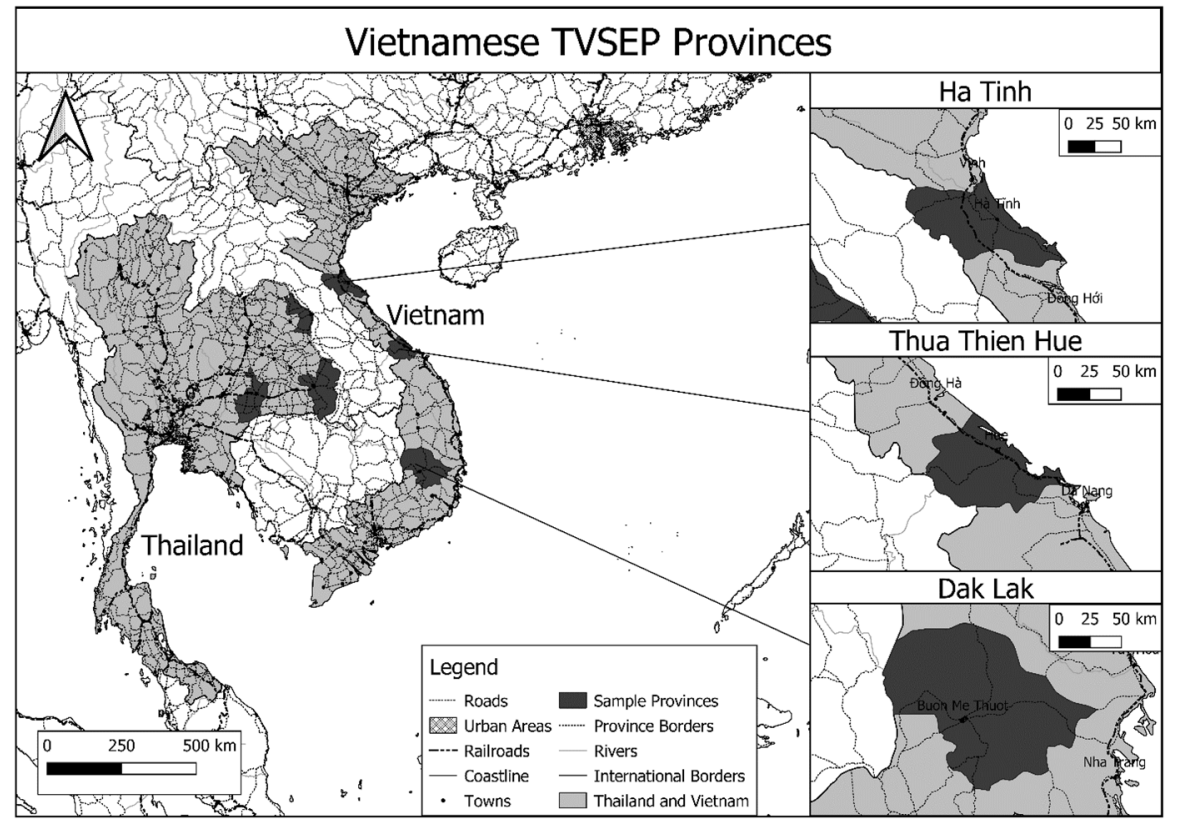

Fig. 2 Map of the Vietnamese provinces covered by the TVSEP project ( Source: Own preparation using QGIS)

In the first step of the three-stage cluster random sampling procedure, subdistricts were sampled according to their share in the district's population. Two villages per subdistrict were then chosen randomly following a similar procedure. Lastly, ten households per village were sampled with equal probabilities. As highlighted in our conceptual framework, we prefer the cross-section over panel analysis to model the short-term benefits of land rental markets. We limit our analysis to households that own cropland and have non-zero crop revenue.

Data collection was divided between a household and a village questionnaire. The household questionnaire contains nine sections that cover individual and household-level information. A combination of individual aspects (such as employment situation and remittances) and those on the household-level (i.e., crop cultivation, livestock raising, extraction of natural resources) facilitates the characterization of livelihood strategies. From the village questionnaire, which is administered to the village head and covers questions regarding infrastructure and public goods at the village level, we obtain information on the distance to the nearest provincial town, community resources and infrastructure, and the number of enterprises in the village.

Land and agriculture form an important section of the household questionnaire as they can provide both a source of income and a cause of vulnerability (Hardeweg et al. 2013, p. 56). Of the 1898 initial households, 938 owned and operated cropland in $2016 / 2017$, and did not have missing values in any of the variables used in the regression analysis. In line with common practice, we exclude outliers identified in 
the factor analysis. Conservatively, we set the cutoff points for outliers to the $1 \mathrm{st}$ and 99th percentile and exclude 146 observations with values below or above that threshold, respectively. ${ }^{2,3}$ Our final sample therefore consists of 792 rural farming households.

In Table 1, we present mean values and shares in total income for income sources by cluster. The first livelihood cluster consists of $313(\approx 40 \%)$ households. These derive a large fraction of their income, and significantly more than the households of the other clusters, from wage labor in agriculture. This supports the notion that poor households in rural Vietnam often resort to this activity (Brünjes and Revilla Diez 2016; Akram-Lodhi 2005; Quang 2018; Prota and Beresford 2012). The second cluster consists of 233 (29\%) households characterized by large incomes from remittances and wages earned in industrial labor, apparently participating in the possibilities offered by the rapid growth of Vietnamese industry and migration to the urban centers (GSO 2011, 2015; Nguyen et al. 2017). The third cluster consists of 57 (7\%) households which earn more than $50 \%$ of their income from crops, livestock, and natural resource extraction. In line with previous research, middle-class households derive more income from natural resources than the poor, both in absolute and relative terms (McElwee 2008; Nguyen and Tran 2018; Nguyen et al. 2015a, b). In the fourth cluster of $59(8 \%)$ households, the cash income from crop production represents the single most income source. A closer look at the data reveals that 49 of those households reside in Dak Lak, where coffee cultivation is prevalent. The 130 $(16 \%)$ households in the fifth cluster derive a large part of their income from selfemployment in a business and wages earned in service jobs. As this cluster is the richest, these households' businesses seem to be driven be economic opportunity rather than necessity (Brünjes and Revilla Diez 2013). In the following, these clusters will be referred to by the name assigned to them because of their dominant livelihood strategy: Cluster 1-Agricultural wage labor; Cluster 2-Migration; Cluster 3-Mixed primary sector activities; Cluster 4-Commercialized farming; and Cluster 5-Self-employment and service jobs.

\section{Results and Discussion}

\section{Determinants of Household Livelihood Strategies}

In this section, we evaluate the role of natural and household capital in determining household livelihood strategies. In Table 2, we present the marginal effects obtained from the estimation of the multinomial logit model. Results from the control function approach are not presented, as the insignificant coefficient of the residual term points to the baseline estimation as the more efficient solution. We observe that our model is reasonably well specified, and accounts for spatial correlation at the village level by bootstrapping standard errors 200 times. Renting in land is associated with a higher probability to belong to the cluster characterized by mixed primary sector activities. Households in this cluster apparently operate the land they rent in to expand their agricultural activities. The important role of land is supported by the positive effect of owned land on the probability of belonging to the migration 
Table 2 MNL determinants of livelihood clusters: marginal effects

Agricultural wage Migration Mixed primary Commerlabor
Self-employment and service jobs farming

\begin{tabular}{|c|c|c|c|c|c|}
\hline \multicolumn{6}{|l|}{ Land } \\
\hline $\mathrm{HH}$ rents in & $\begin{array}{l}-0.095+ \\
(-1.86)\end{array}$ & $\begin{array}{l}0.061 \\
(1.42)\end{array}$ & $\begin{array}{l}0.078^{* * * *} \\
(4.18)\end{array}$ & $\begin{array}{l}-0.013 \\
(-0.19)\end{array}$ & $\begin{array}{l}-0.031 \\
(-0.86)\end{array}$ \\
\hline Owned area & $\begin{array}{l}-0.142 * * * \\
(-3.61)\end{array}$ & $\begin{array}{l}0.161 * * * \\
(5.38)\end{array}$ & $\begin{array}{l}0.016 \\
(0.75)\end{array}$ & $\begin{array}{l}-0.007 \\
(-0.35)\end{array}$ & $\begin{array}{l}-0.028 \\
(-0.79)\end{array}$ \\
\hline rent-out & $\begin{array}{l}-0.142 \\
(-3.61)\end{array}$ & $\begin{array}{l}-0.085 \\
(-0.77)\end{array}$ & $\begin{array}{l}0.015 \\
(0.15)\end{array}$ & $\begin{array}{l}0.013 \\
(0.04)\end{array}$ & $\begin{array}{l}0.084 \\
(1.59)\end{array}$ \\
\hline \multicolumn{6}{|l|}{ Human capital } \\
\hline Age HH head & $\begin{array}{l}-0.003+ \\
(-1.70)\end{array}$ & $\begin{array}{l}-0.000 \\
(-0.09)\end{array}$ & $\begin{array}{l}0.001 \\
(0.67)\end{array}$ & $\begin{array}{l}0.001 \\
(1.21)\end{array}$ & $\begin{array}{l}0.002 \\
(1.23)\end{array}$ \\
\hline Female HH head & $\begin{array}{l}0.098^{*} \\
(2.34)\end{array}$ & $\begin{array}{l}0.027 \\
(0.75)\end{array}$ & $\begin{array}{l}-0.033 \\
(-1.11)\end{array}$ & $\begin{array}{l}-0.039 \\
(-0.90)\end{array}$ & $\begin{array}{l}-0.052 \\
(-1.37)\end{array}$ \\
\hline Min. HH head & $\begin{array}{l}0.146^{* *} \\
(2.82)\end{array}$ & $\begin{array}{l}-0.126^{*} \\
(-2.29)\end{array}$ & $\begin{array}{l}0.020 \\
(0.67)\end{array}$ & $\begin{array}{l}0.008 \\
(0.42)\end{array}$ & $\begin{array}{l}-0.048 \\
(-0.90)\end{array}$ \\
\hline Mean schooling & $\begin{array}{l}-0.017 * * \\
(-2.82)\end{array}$ & $\begin{array}{l}0.004 \\
(0.73)\end{array}$ & $\begin{array}{l}-0.007^{*} \\
(-2.21)\end{array}$ & $\begin{array}{l}0.003 \\
(1.04)\end{array}$ & $\begin{array}{l}0.017^{* *} \\
(3.45)\end{array}$ \\
\hline Adult equivalent & $\begin{array}{l}-0.014 \\
(-0.96)\end{array}$ & $\begin{array}{l}0.019 \\
(1.40)\end{array}$ & $\begin{array}{l}0.003 \\
(0.29)\end{array}$ & $\begin{array}{l}-0.003 \\
(-0.43)\end{array}$ & $\begin{array}{l}-0.004 \\
(-0.38)\end{array}$ \\
\hline \# Migrants & $\begin{array}{l}-0.065^{* *} \\
(-2.78)\end{array}$ & $\begin{array}{l}0.103^{* * *} \\
(6.13)\end{array}$ & $\begin{array}{l}-0.046^{*} \\
(-2.46)\end{array}$ & $\begin{array}{l}0.005 \\
(0.23)\end{array}$ & $\begin{array}{l}0.003 \\
(0.17)\end{array}$ \\
\hline \multicolumn{6}{|l|}{ Physical capital } \\
\hline TLU & $\begin{array}{l}-0.032 \\
(-1.55)\end{array}$ & $\begin{array}{l}0.029+ \\
(1.66)\end{array}$ & $\begin{array}{l}0.007 \\
(0.72)\end{array}$ & $\begin{array}{l}0.010 \\
(1.02)\end{array}$ & $\begin{array}{l}-0.014 \\
(-0.72)\end{array}$ \\
\hline \# Tractors & $\begin{array}{l}-0.101+ \\
(-1.79)\end{array}$ & $\begin{array}{l}0.041 \\
(0.90)\end{array}$ & $\begin{array}{l}0.031 \\
(1.11)\end{array}$ & $\begin{array}{l}0.071 * * * \\
(3.51)\end{array}$ & $\begin{array}{l}-0.043 \\
(-0.71)\end{array}$ \\
\hline $\mathrm{HH}$ transport & $\begin{array}{l}-0.047 \\
(-1.25)\end{array}$ & $\begin{array}{l}-0.065 \\
(-1.58)\end{array}$ & $\begin{array}{l}0.020 \\
(0.95)\end{array}$ & $\begin{array}{l}0.020 \\
(1.03)\end{array}$ & $\begin{array}{l}0.071^{*} \\
(2.34)\end{array}$ \\
\hline \# Boats & $\begin{array}{l}-0.167 \\
(-0.63)\end{array}$ & $\begin{array}{l}0.110 \\
(0.70)\end{array}$ & $\begin{array}{l}0.117^{*} \\
(2.53)\end{array}$ & $\begin{array}{l}-0.030 \\
(-0.10)\end{array}$ & $\begin{array}{l}-.0031 \\
(-0.16)\end{array}$ \\
\hline \multicolumn{6}{|l|}{ Social capital } \\
\hline \# Phones & $\begin{array}{l}-0.096^{* *} \\
(-3.24)\end{array}$ & $\begin{array}{l}0.022 \\
(0.80)\end{array}$ & $\begin{array}{l}-0.020 \\
(-1.25)\end{array}$ & $\begin{array}{l}0.048 * * \\
(2.71)\end{array}$ & $\begin{array}{l}0.046+ \\
(1.82)\end{array}$ \\
\hline SPO & $\begin{array}{l}-0.111^{*} \\
(-2.18)\end{array}$ & $\begin{array}{l}0.079 \\
(1.17)\end{array}$ & $\begin{array}{l}0.001 \\
(0.01)\end{array}$ & $\begin{array}{l}0.004 \\
(0.19)\end{array}$ & $\begin{array}{l}0.028 \\
(0.49)\end{array}$ \\
\hline \multicolumn{6}{|l|}{ Fin. capital } \\
\hline Any Tr. income & $\begin{array}{l}-0.024 \\
(-0.72)\end{array}$ & $\begin{array}{l}-0.087 * * \\
(-2.77)\end{array}$ & $\begin{array}{l}0.009 \\
(0.45)\end{array}$ & $\begin{array}{l}0.027 \\
(1.35)\end{array}$ & $\begin{array}{l}0.076^{* *} \\
(3.16)\end{array}$ \\
\hline HH credit & $\begin{array}{l}-0.030 \\
(-0.81)\end{array}$ & $\begin{array}{l}0.079^{*} \\
(2.22)\end{array}$ & $\begin{array}{l}-0.025 \\
(-1.27)\end{array}$ & $\begin{array}{l}0.023 \\
(0.98)\end{array}$ & $\begin{array}{l}-0.048 \\
(-1.70)\end{array}$ \\
\hline
\end{tabular}


Table 2 (continued)

$\begin{array}{lllll}\begin{array}{l}\text { Agricultural wage } \\ \text { labor }\end{array} & \text { Migration } & \begin{array}{l}\text { Mixed primary } \\ \text { sector activities }\end{array} & \begin{array}{l}\text { Commer- } \\ \text { cialized } \\ \text { farming }\end{array} & \begin{array}{l}\text { Self-employment } \\ \text { and service jobs }\end{array}\end{array}$

\begin{tabular}{llllll}
\hline Village vars & & & & & \\
Distance market & 0.001 & 0.002 & $0.004 * *$ & -0.001 & -0.006 \\
& $(0.31)$ & $(0.33)$ & $(2.65)$ & $(-0.34)$ & $(-1.07)$ \\
Made road & 0.025 & -0.015 & 0.016 & -0.016 & -0.010 \\
& $(0.25)$ & $(-0.15)$ & $(0.10)$ & $(-0.66)$ & $(-0.07)$ \\
Irrigation & -0.046 & -0.003 & 0.009 & -0.017 & $0.058+$ \\
& $(-1.22)$ & $(-0.10)$ & $(0.38)$ & $(-0.91)$ & $(1.73)$ \\
\# Enterprises & 0.006 & -0.024 & 0.006 & -0.006 & 0.018 \\
& $(0.30)$ & $(-1.22)$ & $(0.41)$ & $(-0.29)$ & $(1.43)$ \\
Provinces & Yes & Yes & Yes & Yes & Yes \\
Observations & 792 & & & & \\
Pseudo $R^{2}$ & 0.240 & & & & \\
Log-likelihood & -846.361 & & & & \\
$\chi^{2}$ & 872.561 & & & & \\
$p$-Value $\chi^{2}$ & 0.000 & & & & \\
Mean VIF & 1.295 & & & & \\
B. replications & 200 & & & & \\
\hline
\end{tabular}

$z$ statistics in parentheses; ${ }^{+} p<0.10, * p<0.05, * * p<0.01, * * * p<0.001 .200$ bootstrap replications to account for spatial correlation at village level

cluster. Moreover, a larger owed cropland area reduces the probability to belong to the cluster of agricultural wage labor. This supports the view that shortage of cropland can lead to undesirable livelihood outcomes. Considering the marginal effects of the independent variables, it becomes clear that schooling, migration, and phones can contribute to lifting people out of the agricultural wage labor cluster. Unfortunately, female and minority household heads still seem to struggle in achieving more favorable livelihood outcomes, as indicated by the respective positive, significant marginal effects. The probability to be in the migration cluster is significantly and positively affected by the number of migrants and the access of the household to credit. A minority household head and receiving transfer income reduce that probability. The number of boats and an increased distance to the nearest markets increases the probability to belong to the cluster of mixed primary sector activities. These households seem to rely on agriculture and natural resource extraction possibly because of their distance to towns and markets. The importance of boats indicates a large role of fishing. Accordingly, schooling and migration reduce the probability to belong to this cluster. We turn to the cluster of commercialized farming. The probability of belonging to this cluster is increased by the number of tractors and phones. Being able to communicate prices and work the crop area efficiently with machinery apparently facilitates commercial farming. The probability of belonging to the cluster of self-employment and service jobs is increased by an older household head, higher average years of schooling of adult household members, a 
larger number of means of transport dedicated to non-private uses, and any transfer income a household receives.

Our results are largely supported by the literature. Land ownership (Hoang et al. 2019) and access to land via rental still shape the livelihood strategies of many Vietnamese households (Nguyen et al. 2021). Renting in has been associated with a higher probability of wage employment and medium-scale farming for rural Chinese households (Zhang et al. 2019). Migration serves as strategy to generate remittances (Nguyen et al. 2017; World Bank 2016; UNESCO, UNDP, IOM, UN Habitat 2017), but non-farm sources of income are still hard to access for many ethnic minority households (Tran 2016, 2015). Especially in industries, construction and public service, employment seems to be harder to come by for minorities (Brünjes and Revilla Diez 2016). The same holds for becoming an entrepreneur (Brünjes and Revilla Diez 2013). All of these results agree with our finding that households headed by a minority household head are more likely to pursue agricultural wage labor as dominant livelihood strategy.

\section{Determinants of Commercialization}

In Table 3, we present average partial effects (APEs) on the probability of market participation, the conditional APEs (CAPE) on the log value of sales conditional on participation, and the unconditional APEs (UAPEs), which combine the effect of a variable on the probability of participation and the log quantity sold. Renting in 0.2 hectares of cropland (approx. the mean rented area) increases the probability of market participation by 8.94 percentage points. Moreover, sales quantity conditional on participation is increased by $11.28 \%$. Owning an additional 0.2 hectares of cropland increases the probability of market participation by 5.08 percentage points, the quantity sold conditional on participation by $4.46 \%$, while the unconditional overall effect on sales is $27.7 \%$. Production from rented plots is apparently marketed in larger quantities than that from owned plots, at least when households participate in markets. Our results support the view that access to land, both by owning and renting, facilitates smallholder commercialization (Bernard et al. 2008; Woldeyohanes et al. 2017). They also indicate that scale effects facilitate market participation by enabling farming households to generate surplus production which can be sold on markets (Alene et al. 2008).

The decision to participate in markets is positively affected by the crop revenue, the number of phones held by a household, membership in socio-political organizations, access to credit, and by residing in Thua Thien Hue. Expanding output generates marketable surplus that farmers can sell on markets. Phones can serve to connect farmers to markets and reduce fixed transaction costs (Aker 2010; Tadesse and Bahiigwa 2015). The positive effect of SPO membership can be attributed to the reduction in transaction costs farmers might achieve through collective action (Fischer and Qaim 2012). Access to credit is also associated with a higher probability of market participation, probably because geared toward agricultural inputs, it can facilitate market participation (Alene et al. 2008). Lastly, households in the province 
Table 3 Determinants of commercialization: average partial effects

\begin{tabular}{|c|c|c|c|}
\hline & APE-participation & CAPE—log sales & UAPE—log sales \\
\hline \multicolumn{4}{|l|}{ Land } \\
\hline Crop area rented in & $\begin{array}{l}0.447 * \\
(2.50)\end{array}$ & $\begin{array}{l}0.564 * * \\
(2.59)\end{array}$ & $\begin{array}{l}2.585 \\
(1.38)\end{array}$ \\
\hline Owned crop area & $\begin{array}{l}0.254 * * * \\
(5.24)\end{array}$ & $\begin{array}{l}0.223 * * * \\
(3.46)\end{array}$ & $\begin{array}{l}1.385^{* *} \\
(2.82)\end{array}$ \\
\hline \multicolumn{4}{|l|}{ Output } \\
\hline Crop revenue ${ }^{\#}$ & $\begin{array}{l}0.004 * * * \\
(5.61)\end{array}$ & $\begin{array}{l}0.018 * * * \\
(20.25)\end{array}$ & $\begin{array}{l}0.034 \\
(1.43)\end{array}$ \\
\hline \multicolumn{4}{|l|}{ Human capital } \\
\hline Age HH head & $\begin{array}{l}0.001 \\
(1.39)\end{array}$ & $\begin{array}{l}-0.002 \\
(-0.72)\end{array}$ & $\begin{array}{l}0.005 \\
(0.83)\end{array}$ \\
\hline Female HH head & $\begin{array}{l}-0.006 \\
(-0.20)\end{array}$ & $\begin{array}{l}-0.235^{* *} \\
(-2.64)\end{array}$ & $\begin{array}{l}-0.228 \\
(-1.57)\end{array}$ \\
\hline Minority HH head & $\begin{array}{l}0.018 \\
(0.45)\end{array}$ & $\begin{array}{l}-0.561 * * * \\
(-5.40)\end{array}$ & $\begin{array}{l}-0.397 \\
(-1.64)\end{array}$ \\
\hline Years of schooling adults & $\begin{array}{l}-0.004 \\
(-1.14)\end{array}$ & $\begin{array}{l}0.006 \\
(0.45)\end{array}$ & $\begin{array}{l}-0.016 \\
(-0.95)\end{array}$ \\
\hline Adult equivalents & $\begin{array}{l}-0.021^{*} \\
(-2.15)\end{array}$ & $\begin{array}{l}0.042 \\
(1.33)\end{array}$ & $\begin{array}{l}-0.065 \\
(-1.37)\end{array}$ \\
\hline \multicolumn{4}{|l|}{ Physical capital } \\
\hline TLU & $\begin{array}{l}-0.017 \\
(-1.32)\end{array}$ & $\begin{array}{l}-0.007 \\
(-0.15)\end{array}$ & $\begin{array}{l}-0.087 \\
(-1.01)\end{array}$ \\
\hline \# Tractors & $\begin{array}{l}0.029 \\
(0.64)\end{array}$ & $\begin{array}{l}0.294 * * \\
(3.04)\end{array}$ & $\begin{array}{l}0.390 \\
(1.30)\end{array}$ \\
\hline Transport business use & $\begin{array}{l}-0.024 \\
(-0.89)\end{array}$ & $\begin{array}{l}0.007 \\
(0.08)\end{array}$ & $\begin{array}{l}-0.108 \\
(-0.74)\end{array}$ \\
\hline \multicolumn{4}{|l|}{ Social capital } \\
\hline \# Phones & $\begin{array}{l}0.040+ \\
(1.79)\end{array}$ & $\begin{array}{l}0.096 \\
(1.39)\end{array}$ & $\begin{array}{l}0.269^{*} \\
(2.11)\end{array}$ \\
\hline SPO & $\begin{array}{l}0.073 * \\
(1.97)\end{array}$ & $\begin{array}{l}-0.027 \\
(-0.24)\end{array}$ & $\begin{array}{l}0.320 \\
(1.57)\end{array}$ \\
\hline \multicolumn{4}{|l|}{ Fin. capital } \\
\hline $\mathrm{HH}$ has accessed credit & $\begin{array}{l}0.052 * \\
(2.15)\end{array}$ & $\begin{array}{l}-0.075 \\
(-1.00)\end{array}$ & $\begin{array}{l}0.179 \\
(1.50)\end{array}$ \\
\hline Log off-farm income & $\begin{array}{l}-0.030 * * \\
(-2.73)\end{array}$ & $\begin{array}{l}-0.026 \\
(-0.96)\end{array}$ & $\begin{array}{l}-0.163 * * \\
(-2.60)\end{array}$ \\
\hline \multicolumn{4}{|l|}{ Village vars } \\
\hline Distance market & $\begin{array}{l}-0.008 * * * \\
(-4.19)\end{array}$ & $\begin{array}{l}0.009 \\
(1.40)\end{array}$ & $\begin{array}{l}-0.029 \\
(-1.59)\end{array}$ \\
\hline Made road & $\begin{array}{l}0.004 \\
(0.07)\end{array}$ & $\begin{array}{l}0.005 \\
(0.04)\end{array}$ & $\begin{array}{l}0.023 \\
(0.08)\end{array}$ \\
\hline
\end{tabular}


Table 3 (continued)

\begin{tabular}{llll}
\hline & APE-participation & CAPE-log sales & UAPE-log sales \\
\hline Artificial irrigation & $-0.077 * *$ & $-0.183^{*}$ & $-0.159^{* *}$ \\
& $(-2.77)$ & $(-2.31)$ & $(-3.08)$ \\
Provinces & & & \\
Thua Thien Hue & $0.070^{*}$ & $0.493 * * *$ & $0.753^{* * *}$ \\
& $(2.36)$ & $(5.50)$ & $(4.64)$ \\
Dak Lak & 0.072 & $0.974 * * *$ & $1.172^{* * *}$ \\
& $(1.43)$ & $(8.01)$ & $(3.88)$ \\
Observations & 792 & 677 & 677 \\
Bootstrap replications & & & 200 \\
\hline
\end{tabular}

$t$ statistics in parentheses; ${ }^{+} p<0.10, * p<0.05, * * p<0.01, * * * p<0.001$; Average partial effects (APE) and conditional partial effects (CAPE) are obtained using the margins command in Stata. Values in brackets are bootstrapped standard errors (SE) obtained by the delta method. Unconditional average partial effects (UAPE) and their standard errors were obtained with the program provided in Burke (2009, p. 591), with bootstrapped standard errors obtained in 200 replications

of Thua Thien Hue seem to face fewer difficulties in accessing markets than their counterparts in Ha Tinh province.

On the other hand, more household members, increased off-farm income, distance to markets, and artificial irrigation at the village level reduce the probability of market participation. More household members increase subsistence consumption and reduce the marketable surplus. The effect of pulling labor to increase off-farm income seems to dominate any positive effect the additional funds might have on production technologies (Woldeyohanes et al. 2017). Distance to markets increases the cost and time required for transporting one's output, resulting in a negative coefficient (Alene et al. 2008). An explanation for the negative significant coefficient of irrigation at the village level is that such irrigation is usually targeted at rice production (World Bank 2016). The coefficient might therefore capture that other types of crops are more frequently marketed. The log quantity of sales conditional on market participation is positive and significantly affected by crop revenue and the number of tractors. Also, it is $49.3 \%$ and $97.4 \%$ higher for households from Thua Thien Hue and Dak Lak, respectively. Raising output by one million VND is associated with a $1.8 \%$ increase in quantity sold. Each additional tractor increases household sales by $29.4 \%$. This supports the notion that mechanization can in large part substitute for labor and support the process of rural transformation (Nguyen and Warr 2020). Quantity sold is negatively affected for female- and minority-headed households, which might indicate larger proportional transaction cost in transporting and marketing goods, and differential market access (Key et al. 2000; Alene et al. 2008). Again, we suspect that the coefficient of artificial irrigation captures that rice is commercialized less intensively than other crops. Due to the rigorous treatment with the bootstrapping procedure suggested in Burke (2009), many covariates lose significance in 
the UAPE. However, the UAPE is significant for owned crop area, the number of phones, log off-farm income, artificial irrigation, and the two provinces of Thua Thien Hue and Dak Lak. These findings indicate that access to land, and being able to communicate by mobile phone, represent important pathways to increase the sales of agricultural households. Those households that manage to generate off-farm income seem to attach a reduced importance to sales, possibly indicating a gradual move away from agriculture.

\section{Conclusion}

In this paper, we assess whether renting in additional cropland can help rural households overcome limitations in their livelihood choices and facilitate participation and increased sales in output markets. We employ principal component analysis, cluster analysis, a MNL estimation with a control function approach, and a double-hurdle model. Our results indicate that access to rented land is associated with increased agricultural activities and that both owned and rented lands facilitate market participation and sales quantities in our sample. Households are more likely to belong to clusters that are associated with increased agricultural activities when they rent in. We cannot reject the exogeneity of rented land area using the control function approach. The results of the double-hurdle estimation suggest that rented area can facilitate market participation and increase sales conditional on participation. Our findings entail several policy implications. First of all, the expansion of land rental markets should be a priority for policymakers. Access to rented land is associated with more remunerative livelihoods for households in our sample. This seems to be of special relevance for households that cannot build on a large asset base enabling them to pursue wage or self-employment. Bearing in mind that some households might face higher transaction cost in rental markets, further government action could be targeted specifically to those households. Research can guide this process by providing detailed information on the possible sources of high transaction cost for disadvantaged households (see, e.g., Ricker-Gilbert and Chamberlin (2018)). In line with Huy et al. (2016), we suggest that the Vietnamese government eases the restriction on the conversion of paddy area to other uses, complete the land registration, and improve access to all-weather roads. Bottlenecks for poor household might also be related to low efficiency (Nguyen et al. 2017), which calls for action that enables farmers to access the necessary inputs to increase their efficiency.

Secondly, policies should be tailored to ensure that access to land is combined with the necessary means to cultivate the respective area and sell the output. While the use of tractors has intensified since the 1990s (Takeshima et al. 2018), our results still indicate potential to increase the marketed supply of farmers. Thirdly, households headed by women and minorities are more likely to belong to the agricultural wage labor cluster and sell lower quantities on markets, conditional on market participation. Future research could investigate the differential access to assets and inputs of these groups to explain this phenomenon. Also, possible systematic disadvantages in rental markets would have to be assessed. 
Future research could address some of the limitations of our paper. We had to exclude welfare implications and assumed that commercialization is a desirable livelihood strategy for rural households. Future research could account for the role of rented land and commercialization in household welfare. This would certainly require long-term measures beyond income, for instance, asset accumulation or structural poverty measures. Such an analysis could build on an extended panel data set and consider the dynamics of livelihood strategies rather than short-term strategies. In addition, our study used a sample from only three provinces in one year. Extending the spatial and temporal coverage of the data would allow for better generalization of the findings.

1. The survey instruments and additional information can be accessed under www.tvsep.de.

2. This does not lead to the exclusion of values equal to zero. All variables are either equal to zero at the first percentile, or below zero.

3. A large fraction of the excluded households are coded as outliers due to large negative incomes in crops, livestock, and natural extraction, with 32 observations.

Acknowledgements We thank the members of the institute for environmental economics and world trade and of the institute of development and agricultural economics, both in Hannover, Germany, for intense and useful discussions. We would like to extend our gratitude to the participants of the presentation session "Crop and cropping systems" at the Tropentag 2019 in Kassel, Germany. Lastly, we would like to thank the anonymous reviewer for comments that allowed us to considerably improve the quality of this manuscript, and the Vietnamese households that participated in the survey. This research was supported by the German Research Foundation (DFG) through funding for the project "Armut und nachhaltige Entwicklung: ein Langzeit-Panelprojekt in Thailand und Vietnam, 2015 - 2024 (TVSEP)."

Funding Open Access funding enabled and organized by Projekt DEAL.

\section{Declarations}

Conflict of interest On behalf of all authors, the corresponding author states that there is no conflict of interest.

Open Access This article is licensed under a Creative Commons Attribution 4.0 International License, which permits use, sharing, adaptation, distribution and reproduction in any medium or format, as long as you give appropriate credit to the original author(s) and the source, provide a link to the Creative Commons licence, and indicate if changes were made. The images or other third party material in this article are included in the article's Creative Commons licence, unless indicated otherwise in a credit line to the material. If material is not included in the article's Creative Commons licence and your intended use is not permitted by statutory regulation or exceeds the permitted use, you will need to obtain permission directly from the copyright holder. To view a copy of this licence, visit http://creativecommons.org/licen ses/by/4.0/.

\section{References}

Aker, J.C. 2010. Information from Markets Near and Far: Mobile Phones and Agricultural Markets in Niger. American Economic Journal: Applied Economics 2 (3): 46-59.

Akram-Lodhi, A.H. 2005. Vietnam's Agriculture: Processes of Rich Peasant Accumulation and Mechanisms of Social Differentiation. Journal of Agrarian Change 5 (1): 73-116. 
Alene, A.D., V.M. Manyong, G. Omanya, H.D. Mignouna, M. Bokanga, and G. Odhiambo. 2008. Smallholder Market Participation Under Transactions Costs: Maize Supply and Fertilizer Demand in Kenya. Food Policy 33 (4): 318-328.

Ashley, C., and D. Carney. 1999. Sustainable Livelihoods. Lessons from Early Experience. London: Department for International Development.

Backhaus, K., B. Erichson, W. Plinke, and R. Weiber. 2011. Multivariate Analysemethoden. Eine anwendungsorientierte Einführung. Heidelberg: Springer.

Barrett, C.B. 2008. Smallholder Market Participation: Concepts and Evidence from Eastern and Southern Africa. Food Policy 33 (4): 299-317.

Bergs, S. 1981. Optimalität bei Clusteranalysen: Experimente zur Bewertung Numerischer Klassifikationsverfahren. Dissertation. Münster: Universität Münster.

Bernard, T., A.S. Taffesse, and E. Gabre-Madhin. 2008. Impact of Cooperatives on Smallholder's Commercialization Behavior: Evidence from Ethiopia. Agricultural Economics 39: 147-161.

Bezu, S., G.T. Kassie, B. Shiferaw, and J. Ricker-Gilbert. 2014. Impact of Improved Maize Adoption on Welfare of Farm Households in Malawi: A Panel Data Analysis. World Development 59: 120-131.

Bruinsma, J. 2011. The Resources Outlook: By How Much Do Land, Water and Crop Yields Need to Increase by 2050? In: Piero Conforti (ed.) Looking Ahead in World Food and Agriculture: Perspectives to 2050. Rome, pp. 233-278.

Brünjes, J., and J. Revilla Diez. 2013. 'Recession Push' and 'Prosperity Pull' Entrepreneurship in a Rural Developing Context. Entrepreneurship \&amp; Regional Development 25 (3-4): 251-271.

Brünjes, J., and J. Revilla Diez. 2016. Obtaining Non-Farm Wage Employment in Rural Vietnam. Asia Pacific Viewpoint 57 (2): 263-279.

Burke, W.J. 2009. Fitting and Interpreting Cragg's Tobit Alternative Using Stata. The Stata Journal 9 (4): 584-592.

Cameron, A.C., and P.K. Trivedi. 2010. Microeconometrics Using Stata. College Station, Texas: Stata Press.

Cazzuffi, C., A. McKay, and E. Perge. 2020. The Impact of Agricultural Commercialisation on Household Welfare in Rural Vietnam. Food Policy 94 (4): 101811.

Chapoto, A., et al. 2013. Agricultural Commercialization, Land Expansion, and Homegrown Large-Scale Farmers. IFPRI Discussion Paper, No. 01286. Washington DC

Cragg, J.G. 1971. Some Statistical Models for Limited Dependent Variables with Application to the Demand for Durable Goods. Econometrica 39: 829-844.

Deininger, K. 2003. Land Policies for Growth and Poverty Reduction. Washington, DC: World Bank and Oxford University Press.

Deininger, K., and S. Jin. 2005. The potential of Land Rental Markets in the Process of Economic Development: Evidence from China. Journal of Development Economics 78: 241-270.

Deininger, K., and S. Jin. 2008. Land Sales and Rental Markets in Transition: Evidence from Rural Vietnam. Oxford Bulletin of Economics and Statistics 70 (1): 67-101.

Dube, L. 2016. Determinants of Agriculture Commercialization Among Smallholder Farmers in Manicaland and Masvingo Provinces of Zimbabwe. Agricultural Science Research Journal 6 (8): 182-190.

Fischer, E., and M. Qaim. 2012. Linking Smallholders to Markets: Determinants and Impacts of Farmer Collective Action in Kenya. World Development 40 (6): 1255-1268.

Ghebru, H., and S.T. Holden. 2019. Land Rental Markets and Rural Poverty Dynamics in Northern Ethiopia: Panel Data Evidence Using Survival Models. Review of Development Economics 23 (1): 131-154.

Gebru, M., S.T. Holden, and M. Tilahun. 2019. Tenants' Land Access in the Renal Market: Evidence from Northern Ethiopia. Agricultural Economics 50: 291-302.

Gillespie, J., and T. Le. 2018. From Revolution to Evolution: The Changing Meanings of Socialist Land in Vietnam. In Socialist Law in Socialist East Asia, ed. Fu. Hualing, John Gillespie, Pip Nicholson, and William Partlett, 406-428. Cambridge: Cambridge University Press.

Goetz, S.A. 1992. A Selectivity Model of Household Food Marketing Behaviour in Sub-Saharan Africa. American Journal of Agricultural Economics 74 (2): 444-452.

GSO. 2011. Migration and Urbanization in Vietnam: Patterns, Trends and Differentials. Vietnam Population and Housing Census, Hanoi, VN.

GSO. 2015. The 2015 National Internal Migration Survey: Major Findings, Hanoi, VN.

Hardeweg, B., S. Klasen, and H. Waibel. 2013. Establishing a Database for Vulnerability Assessment. In Vulnerability to Poverty: Theory, Measurement and Determinants, with Case Studies from Thailand and Vietnam, ed. Stephan Klasen and Hermann Waibel, 50-79. London: Palgrave Macmillan UK. 
Heckman, J.J. 1979. Sample Selection Bias as a Specification Error. Econometrica 47: 153-161.

Hirsch, P., Mellac, M., and Scurrah, N. 2015. The Political Economy of Land Governance in Viet Nam. Vientiane, Lao PDR: Mekong Region Land Governance.

Hoang, V.C., T.Q. Tran, Y.H.T. Nguyen, and K.D. Nguyen. 2019. Is Land Ownership a Key Factor in the Choice of Livelihood in the Mekong Delta, Vietnam? Human Ecology 47 (5): 681-691.

Huy, H.T., M. Lyne, N. Ratna, and P. Nuthall. 2016. Drivers of Transaction Costs Affecting Participation In the Rental Market for Cropland in Vietnam. Australian Journal of Agricultural and Resource Economics 60: 476-492.

Huy, H.T., and T.T. Nguyen. 2019. Cropland Rental Market and Farm Technical Efficiency in Rural Vietnam. Land Use Policy 81: 408-423.

Jansen, H.G., J. Pender, A. Damon, W. Wielemaker, and R. Schipper. 2006. Policies for Sustainable Development in the Hillside Areas of Honduras: A Quantitative Livelihoods Approach. Agricultural Economics 34 (2): 141-153.

Jin, S., and K. Deininger. 2009. Land Rental Markets in the Process of Rural Structural Transformation: Productivity and Equity Impacts from China. Journal of Comparative Economics 37: 629-646.

Jin, S., and T.S. Jayne. 2013. Land Rental Markets in Kenya: Implications for Efficiency, Equity, Household Income, and Poverty. Land Economics 89 (2): 246-271.

Key, N., E. Sadoulet, and A. de Janvry. 2000. Transaction Costs and Agricultural Household Supply Response. American Journal of Agricultural Economics 82: 245-259.

Kissoly, L.D. 2016. Food Security Outcomes of Smallholders' Integration in Traditional Agricultural Value Chains in Tanzania and Kenya. Dissertation, Hannover, Germany: Leibniz Universität.

Markussen, T. 2015. Land Issues in Vietnam 2006-2014. WIDER Working Paper 2015/088.

Marsh, S.P., MacAulay, T.G., and Pham, V.H. 2006) Agricultural Development and Land Policy in Vietnam. Canberra: ACIAR.

McElwee, P.D. 2008. Household Socioeconomic Factors Influencing Forest Use. Environmental Conservation 35 (2): 147-159.

Momtaz, S., and M.I.M. Shameem. 2016. Adaptation in Climate Change Discourse: A Conceptual Framework. In Salim Momtaz, ed. M.I.M. Shameem, 7-28. Experiencing Climate Change in Bangladesh. Amsterdam: Elsevier.

Muraoka, R., T.S. Jayne, and S. Jin. 2018. Land Access, Land Rental and Food Security: Evidence from Kenya. Land Use Policy 70: 611-622.

Muriithi, B.W., and J.A. Matz. 2014. Smallholder Participation in the Commercialization of Vegetables: Evidence from Kenyan Panel Data. Quarterly Journal of International Agriculture 2: 141-168.

Nguyen, T.T., T.L. Do, D. Bühler, R. Hartje, and U. Grote. 2015b. Rural Livelihoods and Environmental Resource Dependence in Cambodia. Ecological Economics 120: 282-295.

Nguyen, D.L., U. Grote, and T.T. Nguyen. 2017. Migration and Rural Household Expenditures: A Case Study from Vietnam. Economic Analysis and Policy 56: 163-175.

Nguyen, L.D., K. Raabe, and U. Grote. 2015a. Rural-Urban Migration, Household Vulnerability, and Welfare in Vietnam. World Development 71: 79-93.

Nguyen, T.V., and T.Q. Tran. 2018. Forestland and Rural Household Livelihoods in the North Central Provinces. Vietnam. Land Use Policy 79: 10-19.

Nguyen, T.T., T. Tran, T.-T. Nguyen, and U. Grote. 2021. Farming Efficiency, Cropland Rental Market and Income Effect: Evidence from Panel Data for Rural Central Vietnam. European Review of Agricultural Economics 48: 207-248.

Nielsen, O.J., S. Rayamajhi, P. Uberhuaga, H. Meilby, and C. Smith-Hall. 2013. Quantifying Rural Livelihood Strategies in Developing Countries Using an Activity Choice Approach. Agricultural Economics 44: 57-71.

Ogutu, S. O., et al. 2017. Agricultural Commercialization and Nutrition in Smallholder Farm Households. GlobalFood Discussion Papers, No. 97. Göttingen.

Ogutu, S.O., and M. Qaim. 2019. Commercialization of the Small Farm Sector and Multidimensional Poverty. World Development 114: 281-293.

Omiti, J. M., Otieno, D. J., Nyanamba, T. O. and McCullough, E. B. (2009) Factors influencing the intensity of market participation by smallholder farmers: A case study of rural and peri-urban areas of Kenya. African Journal of Agricultural and Resource Economics 3(1): 2009.

Petrin, A., and K. Train. 2010. A Control Function Approach to Endogeneity in Consumer Choice Models. Journal of Marketing Research 47 (1): 3-13.

Pham, H.T., Tuan, B.A. and Le Thanh, D. 2010. Is Nonfarm Diversification a Way Out of Poverty for Rural Households? Evidence from Vietnam in 1993-2006. PEP Working Paper Serie 2010-17. 
Prota, L., and M. Beresford. 2012. Emerging Class Relations in the Mekong River Delta of Vietnam: A Network Analysis. Journal of Agrarian Change 12 (1): 60-80.

Qin, H., and T.F. Liao. 2016. Labor Out-Migration and Agricultural Change in Rural China: A Systematic Review and Meta-Analysis. Journal of Rural Studies 47 (B): 533-541.

Quang, T.H. 2018. Land Accumulation in the Mekong Delta of Vietnam: A Question Revisited. Canadian Journal of Development Studies 39 (2): 199-214.

Ravallion, M., and D. van de Walle. 2008. Land in Transition. Reform and Poverty in Rural Vietnam. Washington, DC and Houndmills: World Bank and Palgrave Macmillan.

Ricker-Gilbert, J., and J. Chamberlin. 2018. Transaction Costs, Land Rental Markets, and Their Impact on Youth Access to Agriculture in Tanzania. Land Economics 94 (4): 541-555.

Serrat, O. 2008. The Sustainable Livelihoods Approach. Washington, DC: Cornell University ILR School.

Tadesse, G., and G. Bahiigwa. 2015. Mobile Phones and Farmers' Marketing Decisions in Ethiopia. World Development 68: 296-307.

Takeshima, H., et al. 2018. Evolution of Agricultural Mechanization in Vietnam: Insights from a Literature Review and Multiple Rounds of a Farm Household Survey. IFPRI Discussion Paper, No. 01724. Washington D.C.

Tipraqsa, P., and P. Schreinemachers. 2009. Agricultural Commercialization of Karen Hill Tribes in Northern Thailand. Agricultural Economics 40: 43-53.

Tobin, J. 1958. Estimation of Relationships for Limited Dependent Variables. Econometrica 26: 24-36.

Tran, T.Q. 2016. Income Sources and Inequality Among Ethnic Minorities in the Northwest Region, Vietnam. Environment, Development and Sustainability 18: 1239-1254.

Tran, T.Q., and H. van Vu. 2019. Land Fragmentation and Household Income: First Evidence from Rural Vietnam. Land Use Policy 89: 1-8.

UNESCO, UNDP, IOM, UN Habitat. 2017. Overview of Internal Migration in Viet Nam. Bangkok.

von Braun, J., and M.D.C. Immink. 1994. Non-Traditional Vegetable Crops and Food Security Among Smallholder Farmers in Guatemala. In Agricultural Commercialization, Economic Development and Nutrition, ed. Joachim von Braun and Eileen Kennedy, 189-203. Baltimore MD: John Hopkins University Press.

Waledign, S.Z. 2017. Getting Stuck, Falling Behind or Moving Forward: Rural Livelihood Movements and Persistence in Nepal. Land Use Policy 65: 294-307.

Winter-Nelson, A., and A. Temu. 2005. Impacts of Prices and Transaction Costs on Input Usage in a Liberalizing Economy: Evidence from Tanzanian Coffee Growers. Agricultural Economics 33: 243-253.

Woldeyohanes, T., T. Heckelei, and Y. Surry. 2017. Effect of Off-Farm Income on Smallholder Commercialization: Panel Evidence from Rural Households in Ethiopia. Agricultural Economics 48: 207-218.

Wooldridge, J.M. 2005. Unobserved Heterogeneity and Estimation of Average Partial Effects. In Identification and Inference for Econometric Models: Essays in Honor of Thomas Rothenberg, ed. D.W.K. Andrews and J.H. Stock, 27-55. Cambridge: Cambridge University Press.

Wooldridge, J.M. 2010. Econometric Analysis of Cross Section and Panel Data. Cambridge, London: MIT Press.

Wooldridge, J.M. 2015. Control Function Methods in Applied Econometrics. Journal of Human Resources 50 (2): 420-445.

World Bank (2016) Transforming Vietnamese Agriculture: Gaining More from Less. Hanoi, VN.

World Bank. 2020. World Development Indicators: Arable Land (Hectares Per Person). https://data.world bank.org/indicator/AG.LND.ARBL.HA.PC?view=chart. Accessed 11 February 2020.

Zhang, J., A.K. Mishra, and P. Zhu. 2019. Identifying livelihood strategies and transitions in rural China: Is land holding an obstacle. Land Use Policy 80: 107-117.

Zhang, L., S. Feng, N. Heerink, F. Qu, and A. Kuyvenhoven. 2018. How Do Land Rental Markets Affect Household Income? Evidence from Rural Jiangsu, P.R. China. Land Use Policy 74: 151-165.

Publisher's Note Springer Nature remains neutral with regard to jurisdictional claims in published maps and institutional affiliations. 